\title{
Commentary on: "Detection of Toxoplasma gondii in raw caprine, ovine, buffalo, bovine, and camel milk using cell cultivation, cat bioassay, capture ELISA, and PCR methods in Iran"
}

\author{
Sonia Boughattas * \\ Department of Environmental and Biological Chemistry, College of Agriculture, Life and Environmental Sciences, Chungbuk \\ National University, Cheongju, South Korea
}

Keywords: Toxoplasma, infection, foodborne, milk, consumption

\section{A commentary on}

OPEN ACCESS

Edited by:

Veeranoot Nissapatorn, University of Malaya, Malaysia

Reviewed by:

Helieh S. Oz, University of Kentucky Medical Center,

USA

*Correspondence: Sonia Boughattas, sbgh@mail.com

Specialty section: This article was submitted to Microbial Immunology, a section of the journal

Frontiers in Microbiology

Received: 12 November 2014 Accepted: 03 March 2015 Published: 18 March 2015

Citation:

Boughattas S (2015) Commentary on: "Detection of Toxoplasma gondii in raw caprine, ovine, buffalo, bovine, and camel milk using cell cultivation, cat bioassay, capture ELISA, and PCR methods in Iran".

Front. Microbiol. 6:215.

doi: 10.3389/fmicb.2015.00215
Detection of Toxoplasma gondii in raw caprine, ovine, buffalo, bovine, and camel milk using cell cultivation, cat bioassay, capture ELISA, and PCR methods in Iran

Dehkordi, F. S., Borujeni, M. R., Rahimi, E., and Abdizadeh, R. (2013). Foodborne Pathog. Dis. 10, 120-125. doi: 10.1089/fpd.2012.1311

Comments on "detection of Toxoplasma gondii in raw caprine, ovine, buffalo, bovine, and camel milk using cell cultivation, cat bioassay, capture ELISA, and PCR methods in Iran."

Dubey, J. P., and Jones, J. L. (2014). Foodborne Pathog. Dis. 11, 500-501. doi: 10.1089/fpd.2014.1786

As it is known, toxoplamsosis occurs mainly by foodborne transmission: ingestion of raw or undercooked meat; unwashed fruit/vegetables, unhygienic water, or contaminated milk. Gaps in the concerning risk assessment of Toxoplasma gondii (T. gondii) by milk consumption are noted.

Recently, a paper launched a debate about milk contamination (Dehkordi et al., 2013). The authors reported the detection of the toxoplasmic DNA in milk of different naturally infected herds (ovine, caprine) including low sensitive hosts to the parasite (bovine, camels, buffalo). American scientists (Dubey and Jones, 2014) commented the findings pointing out some technical gaps about the sensitivity of employed methods (e.g., high rate of parasite detection by bioassay and cell culture), rising thus interrogations and seeking independent reproduction of data to affirm the reported conclusion.

Risk assessment studies associating T. gondii infections and milk consumption showed wide divergence. While some papers reported positive correlations between drinking milk and humans infection in Poland (Paul, 1998), USA (Jones et al., 2009), Mexico (Alvarado-Esquivel et al., 2010); other studies stated non-significant influence of milk or milk products consumption among pregnant women in Jordan (Nimri et al., 2004) and high risked populations in Kyrgyzstan (Minbaeva et al., 2013).

Essentially, outbreaks of human toxoplasmosis were reported mainly by the ingestion of raw (unpasteurized) goat milk with the contamination of 10 members from 24 individuals composed family. The authors stated serological evidence of acute T. gondii infection (One subject with 
retinochoroiditis and the other 9 persons had asymptomatic infections). All 10 seropositive persons had recently consumed raw goat's milk from the family herd as compared with no consumption of raw milk by the 14 persons with negative results. No dietary item or other risk factors were as strongly associated with positive serological test results as raw milk consumption (Sacks et al., 1982). Studies worldwide attempted to analyze the risk factor of raw goat milk consumption among different populations: in Brazil when targeting pregnant women (Avelino et al., 2003; Barbosa et al., 2009; Moura et al., 2013); in Saudi Arabia targeting the same population (Almushait et al., 2014); in USA questioning a global population (Jones et al., 2009); in Mexico focusing on agricultural workers (Alvarado-Esquivel et al., 2013) and in Ethiopia investigating women population in general (Gebremedhin et al., 2013).

It has often been thought that the risk of acquiring an infection with $T$. gondii by drinking goat's milk is high and cow's milk, if any, is minimal. However, it was shown that only $1.6 \%$ of the control patients in USA specified they drank unpasteurized goat's milk in the past 12 months (Jones et al., 2009). Consequently consumption of unpasteurized goat's milk is retained relatively uncommon in the United States. Lately it was found that $14.1 \%$ of the seropositive pregnant women in Brazil had the habit of consuming raw cow's or/and goat's milk (Moura et al., 2013). When risk factors analyzed, unpasteurized/raw cow's milk consumption wasn't associated with toxoplasmic infection among agricultural workers in Mexico (Alvarado-Esquivel et al., 2013) as well in Brazil when targeting immune-competent population (Bahia-Oliveira et al., 2003). However other studies reported significant association between milk/dairy consumption and toxoplasmosis occurrence: in Brazil (Heukelbach et al., 2007; Santos et al., 2009; Silva et al., 2014); in Mexico (AlvaradoEsquivel et al., 2010); in Egypt (Elsheikha et al., 2009) and in Iran (Fouladvand et al., 2010).

Positive correlation was also retained with the consumption of other animals milk. Indeed, risk factors analysis reported the consumption of raw buffalo dairy products in British Columbia (Proctor and Banerjee, 1994) and in Egypt among blood donors (Elsheikha et al., 2009). Sheep milk involvement in toxoplasmosis occurrence was also investigated as potential risk factors in Ethiopia (Gebremedhin et al., 2013) when targeting women population as well as in Brazil (Barbosa et al., 2009) when targeting pregnant females.

\section{References}

Almushait, M. A., Dajem, S. M., Elsherbiny, N. M., Eskandar, M. A., Al Azraqi, T. A., and Makhlouf, L. M. (2014). Seroprevalence and risk factors of Toxoplasma gondii infection among pregnant women in south western, Saudi Arabia. J. Parasit. Dis. 38, 4-10. doi: 10.1007/s12639-012-0195-z

Alvarado-Esquivel, C., Campillo-Ruiz, F., and Liesenfeld, O. (2013). Seroepidemiology of infection with Toxoplasma gondii in migrant agricultural workers living in poverty in Durango, Mexico. Parasit Vectors 6:113. doi: 10.1186/17563305-6-113
Few other studies investigated the detection of natural infection of the parasite within less consumed milk from camel and donkeys. In Iran, scientists reported a rate of camel milk contamination of $3.12 \%$ by culture bioassays (Dehkordi et al., 2013). In the frame of seroepidemiological investigation within camels, Ethiopian team revealed that $100 \%$ of the animal owners had consumed raw camel milk (Gebremedhin et al., 2014). Concerning T. gondii prevalence in the milk matrix of donkeys, only three studies investigated its analysis. Scientists in Egypt were able to detect the toxoplasmic antibodies in $46.3 \%$ of milk samples (Haridy et al., 2010). In Europe, Italian studies using molecular tools reported the detection of $T$. gondii DNA in 66.66\% (Mancianti et al., 2014) and in $22.22 \%$ (Martini et al., 2014) of analyzed donkeys' milk samples.

The toxoplasmic transmission was attributed both to tachyzoites in the milk and to suckling. Toxoplasmosis was described in breast fed child whose mother had recently acquired toxoplasmosis (Azab et al., 1992; Bonametti et al., 1997). Moreover, mammary glands can be contaminated from environment and suckling calf-camel can acquire toxoplasmosis from milk/nipples of their infected mother. The toxoplasmic contamination is worsened due to smaller concentration of proteolytic enzymes that counter the parasite infection in the intestine of children and suckling animals (Ishag et al., 2006). It was experimentally confirmed that tachyzoites survived in the milk for three to 7 days at $4{ }^{\circ} \mathrm{C}$ (Spišák et al., 2010) and in homemade fresh cheese for a period of 10 days (Hiramoto et al., 2001), proving consequently that raw milk can serve as a source of T.gondii infection.

Proponents of raw milk claim that unpasteurized milk/dairy products are more nutritive than pasteurized ones, even if it is stated elsewhere with equal nutritional values (Claeys et al., 2013). It was reported that many Americans consume products labeled as "organic" or from food cooperatives (Dubey and Jones, 2014). In Europe and according to the regional legislations; raw milk from any species can be sold immediately after milking by the producer or a local milk seller to the consumer, without any thermal treatment except refrigeration between 0 and $4^{\circ} \mathrm{C}$ (Mancianti et al., 2014).

Given that, the increase of organic milk demand, and in the light of these recent observations, there is great concern regarding whether it is safe to consume raw milk. Deeper analysis should be investigated and special awareness should be taken by consumers with the insistence on of heat treatment of the milk before consumption.
Alvarado-Esquivel, C., Liesenfeld, O., Torres-Castorena, A., Estrada-Martinez, S., Urbina-Alvarez, J. D., Ramos-de la Rocha, M., et al. (2010). Seroepidemiology of Toxoplasma gondii infection in patients with vision and hearing impairments, cancer, HIV, or undergoing hemodialysis in Durango, Mexico. J. Parasitol. 96, 505-508. doi: 10.1645/GE2378.1

Avelino, M. M., Campos, D. Jr., do Carmo Barbosa de Parada, J., and de Castro, A. M. (2003). Pregnancy as a risk factor for acute toxoplasmosis seroconversion. Eur. J. Obstet. Gynecol. Reprod. Biol. 108, 19-24. doi: 10.1016/S03012115(02)00353-6 
Azab, M. E., Kamel, A. M., Makled, K. M., Khattab, H., el-Zayyat, E. A., Abo-Amer, E. A., et al. (1992). Naturally occurring toxoplasma antibodies in serum and milk of lactating women. J. Egypt. Soc. Parastiol. 22, 561-568.

Bahia-Oliveira, L. M., Jones, J. L., Azevedo-Silva, J., Alves, C. C., Oréfice, F., and Addiss, D. G. (2003). Highly endemic, waterborne toxoplasmosis in north Rio de Janeiro state, Brazil. Emerg. Infect. Dis. 9, 55-62. doi: 10.3201/eid0901.020160

Barbosa, I. R., de Carvalho Xavier Holanda, C. M., and de Andrade-Neto, V. F. (2009). Toxoplasmosis screening and risk factors amongst pregnant females in Natal, northeastern Brazil. Trans. R. Soc. Trop. Med. Hyg. 103: 377-382. doi: 10.1016/j.trstmh.2008.11.025

Bonametti, A. M., Passos, J. N., Koga de Silva, E. M., and Macedo, Z. S. (1997). Probable transmission of acute toxoplasmosis through breast feeding. J. Trop. Pediatr. 43, 116 doi: 10.1093/tropej/43.2.116

Claeys, W. L., Cardoen, S., Daube, G., De Block, J., Dewettinck, K., Dierick, K., et al. (2013). Raw or heated cow milk consumption: review of risks and benefits. Food Control 31, 251-262. doi: 10.1016/j.foodcont.2012.09.035

Dehkordi, F. S., Borujeni, M. R., Rahimi, E., and Abdizadeh, R. (2013). Detection of Toxoplasma gondii in raw caprine, ovine, buffalo, bovine, and camel milk using cell cultivation, cat bioassay, capture ELISA, and PCR methods in Iran. Foodborne Pathog. Dis. 10, 120-125. doi: 10.1089/fpd.2012.1311

Dubey, J. P., and Jones, J. L. (2014). Comments on "detection of Toxoplasma gondii in raw caprine, ovine, buffalo, bovine, and camel milk using cell cultivation, cat bioassay, capture ELISA, and PCR methods in Iran." Foodborne Pathog. Dis. 11, 500-501. doi: 10.1089/fpd.2014.1786

Elsheikha, H. M., Azab, M. S., Abousamra, N. K., Rahbar, M. H., Elghannam, D. M., and Raafat, D. (2009). Seroprevalence of and risk factors for Toxoplasma gondii antibodies among asymptomatic blood donors in Egypt. Parasitol. Res. 104, 1471-1476. doi: 10.1007/s00436-009-1350-Z

Fouladvand, M., Barazesh, A., Naeimi, B., Zandi, K., and Tajbakhsh, S. (2010). Seroprevalence of toxoplasmosis in high school girls in Bushehr city, Southwest of Iran 2009. Afr. J. Microbiol. Res. 4, 1117-1121. doi: 10.5897/ AJB10.388

Gebremedhin, E. Z., Abebe, A. H., Tessema, T. S., Tullu, K. D., Medhin, G., Vitale, M., et al. (2013). Seroepidemiology of Toxoplasma gondii infection in women of child-bearing age in central Ethiopia. BMC Infect. Dis. 13, 101. doi: 10.1186/1471-2334-13-101

Gebremedhin, E. Z., Yunus, H. A., Tesfamaryam, G., Tessema, T. S., Dawo, F., Terefe, G., et al. (2014). First report of Toxoplasma gondii in camels (Camelus dromedarius) in Ethiopia: bioassay and seroepidemiological investigation. BMC Vet. Res. 10:222. doi: 10.1186/s12917-014-0222-7

Haridy, F. M., Saleh, N. M., Khalil, H. H., and Morsy, T. A. (2010). AntiToxoplasma gondii antibodies in working donkeys and donkey's milk in greater Cairo, Egypt. J. Egypt Soc. Parasitol. 40, 459-464.

Heukelbach, J., Meyer-Cirkel, V., Moura, R. C., Gomide, M., Queiroz, J. A., Saweljew, P., et al. (2007). Waterborne toxoplasmosis, northeastern Brazil. Emerg. Infect. Dis. 13, 287-289. doi: 10.3201/eid1302.060686

Hiramoto, R. M., Mayrbaurl-Borges, M., Galisteo, A. J. Jr., Meireles, L. R., Macre, M. S., Andrade, H. F., et al. (2001). Infectivity of cysts of the ME-49 Toxoplasma gondii strain in bovine milk and homemade cheese. Rev. Saude Publica 35, 113-118. doi: 10.1590/S0034-89102001000200002

Ishag, M. Y., Magzoub, E., and Majid, M. (2006). Detection of Toxoplasma gondii tachyzoites in the milk of experimentally infected lacting She-Camels. J. Anim. Vet. Adv. 5, 456-458.
Jones, J. L., Dargelas, V., Roberts, J., Press, C., Remington, J. S., and Montoya, J. G. (2009). Risk factors for Toxoplasma gondii infection in the United States. Clin. Infect. Dis. 49, 878-884. doi: 10.1086/605433

Mancianti, F., Nardoni, S., Papini, R., Mugnaini, L., Martini, M., Altomonte, I., et al. (2014). Detection and genotyping of Toxoplasma gondii DNA in the blood and milk of naturally infected donkeys (Equus asinus). Parasit Vectors 7, 165. doi: 10.1186/1756-3305-7-165

Martini, M., Altomonte, I., Mancianti, F., Nardoni, S., Mugnaini, L., and Salari, F., A (2014). preliminary study on the quality and safety of milk in donkeys positive for Toxoplasma gondii. Animal 8, 1996-1998. doi: $10.1017 /$ S1751731114001980

Minbaeva, G., Schweiger, A., Bodosheva, A., Kuttubaev, O., Hehl, A. B., Tanner, I., et al. (2013). Toxoplasma gondii infection in Kyrgyzstan: seroprevalence, risk factor analysis, and estimate of congenital and AIDS-related toxoplasmosis. PLoS Negl. Trop. Dis. 7:e2043. doi: 10.1371/journal.pntd. 0002043

Moura, F. L., Amendoeira, M. R., Bastos, O. M., Mattos, D. P., Fonseca, A. B., Nicolau, J. L., et al. (2013). Prevalence and risk factors for Toxoplasma gondii infection among pregnant and postpartum women attended at public healthcare facilities in the City of Niteroi, State of Rio de Janeiro, Brazil. Rev. Soc. Bras. Med. Trop. 46, 200-207. doi: 10.1590/0037-8682-1613-2013

Nimri, L., Pelloux, H., and Elkhatib, L. (2004). Detection of Toxoplasma gondii DNA and specific antibodies in high-risk pregnant women. Am. J. Trop. Med. Hyg. 71, 831-835.

Paul, M. (1998). Potential risk factors for Toxoplasma gondii infection in cases with recently acquired toxoplasmosis. Przegl. Epidemiol. 52, 447-454.

Proctor, E. M., and Banerjee, S. N. (1994). The seroepidemiology of toxoplasmosis in the lower Fraser Valley of British Columbia. Can. J. Infect. Dis. 5, 218-223.

Sacks, J. J., Roberto, R. R., and Brooks, N. F. (1982). Toxoplasmosis infection associated with raw goat's milk. JAMA 248, 1728-1732. doi: 10.1001/jama.1982.03330140038029

Santos, T. R., Costa, A. J., Toniollo, G. H., Luvizotto, M. C., Benetti, A. H., Santos, R. R., et al. (2009). Prevalence of anti-Toxoplasma gondii antibodies in dairy cattle, dogs, and humans from the Jauru micro-region, Mato Grosso state, Brazil. Vet. Parasitol. 161, 324-326. doi: 10.1016/j.vetpar.2009. 01.017

Silva, M. G., Camara, J. T., Vinaud, M. C., and de Castro, A. M. (2014). Epidemiological factors associated with seropositivity for toxoplasmosis in pregnant women from Gurupi, State of Tocantins, Brazil. Rev. Soc. Bras. Med. Trop. 47, 469-475. doi: 10.1590/0037-8682-0127-2014

Spišák, F., Turčeková, L., Reiterová, K., špilovská, Á S., and Dubinský, P. (2010). Prevalence estimation and genotypization of Toxoplasma gondii in goats. Biologia 65, 670-674. doi: 10.2478/s11756-010-0070-2

Conflict of Interest Statement: The author declares that the research was conducted in the absence of any commercial or financial relationships that could be construed as a potential conflict of interest.

Copyright (c) 2015 Boughattas. This is an open-access article distributed under the terms of the Creative Commons Attribution License (CC BY). The use, distribution or reproduction in other forums is permitted, provided the original author (s) or licensor are credited and that the original publication in this journal is cited, in accordance with accepted academic practice. No use, distribution or reproduction is permitted which does not comply with these terms. 